\title{
SOCIAL REPRESENTATIONS OF THE BRAZILIAN NATIONAL HEALTH CARE SYSTEM IN THE CITY OF RIO DE JANEIRO, BRAZIL, ACCORDING TO THE STRUCTURAL APPROACH
}

\author{
Antonio Marcos Tosoli Gomes ${ }^{1}$ \\ Denize Cristina de Oliveira ${ }^{2}$ \\ Celso Pereira de Sá3
}

Gomes AMT, Oliveira DC, Sá CP. Social representations of the Brazilian national health care system in the city of Rio de Janeiro, Brazil, according to the structural approach. Rev Latino-am Enfermagem 2008 janeirofevereiro; $16(1): 122-9$.

The Brazilian National Health Care System - The Single Health System (SHS) [SUS-Sistema Único de Saúde] faces difficulties for its effective implementation. This paper aims to characterize the contents and the social representation structure of the Brazilian health care system among health care professionals in the city of Rio de Janeiro. The concept of social memory and the theory of social representation were adopted as frameworks. Five health care institutions were included in this research, with 100 professionals altogether. The free-association technique was used to collect data and the EVOC 2003 software was used analyzed for data analysis. The results signal to a central nucleus, characterized by negative attitudes regarding the SUS. In the contrast area, there is a negative attitude towards the effectiveness of the system and a positive attitude towards the care provided to service users, also showing other principles. At its periphery, the implementation of new opinions about the representation could be observed. It is concluded that the professionals present social representations that recognize the SUS as a new system, eliciting negative attitudes among the professionals, and that is in a process of formation or progressive transformation, raising judgments about the pertinence of the system's principles.

DESCRIPTORS: memory; health systems; single health system

\section{REPRESENTACIONES SOCIALES DEL SISTEMA ÚNICO DE SALUD EN EL MUNICIPIO DE RÍO DE JANERO, BRASIL, SEGÚN EL ENFOQUE ESTRUCTURAL}

El sistema único de salud (SUS) enfrenta dificultades para una efectiva implementación. Este estudio tiene por objetivo caracterizar los contenidos y la estructura de las representaciones profesionales sobre la implementación del SUS en la ciudad de Río de Janeiro. Fueron adoptadas como guías la Teoría de Representación y Memoria Social, desarrolladas en cinco instituciones con cien profesionales. Los datos fueron recolectados a través de narraciones espontáneas y posteriormente analizados por el software EVOC2000. Los resultados muestran un núcleo central que se caracterizan por actitudes negativas frente al SUS. En el área de contraste se observa una actitud negativa que se refiere a la funcionalidad y una positiva, relacionada a la atención de los usuarios. En las zonas periféricas de la ciudad fue observada la incorporación de nuevos posicionamientos frente a la representación. Se concluye que en los profesionales se observan representaciones sociales que reconocen al SUS como un nuevo sistema. Sin embargo, esta incorporación no se da de forma natural, generando críticas sobre la importancia de los principios del sistema.

DESCRIPTORES: memoria; sistema de salud; sistema único de salud

\section{AS REPRESENTAÇÕES SOCIAIS DO SISTEMA ÚNICO DE SAÚDE NO MUNICÍPIO DO RIO DE JANEIRO, BRASIL, SEGUNDO A ABORDAGEM ESTRUTURAL}

O Sistema Único de Saúde (SUS) enfrenta dificuldades para a sua efetiva implementação. Este estudo objetivou caracterizar os conteúdos e a estrutura das representações dos profissionais acerca da implantação do SUS no município do Rio de Janeiro. Adotou-se como eixos orientadores a Teoria de Representação e de Memória Social, sendo desenvolvido em 5 instituições de saúde, com 100 profissionais. Os dados foram coletados através de evocações livres e analisados pelo software EVOC 2000. Os resultados revelam um núcleo central caracterizado por atitudes negativas frente ao SUS. Na zona de contraste, observa-se atitude negativa referida à funcionalidade e positiva relativa ao atendimento dos usuários. Na periferia, percebe-se a incorporação de novos posicionamentos à representação. Conclui-se que os profissionais apresentam representações sociais que reconhecem o SUS como um novo sistema. No entanto, essa incorporação não vem ocorrendo de forma naturalizada, mas desperta julgamentos sobre a pertinência dos princípios do sistema.

1.Ph.D. in Nursing, Adjunct Professor, e-mail: mtosoli@gmail.com; 2. Ph.D. in Public Health, Full Professor, e-mail: dcouerj@gmail.com. Rio de Janeiro State University School of Nursing, Brazil; ${ }^{3}$ Ph.D. in Psychology, Full Professor, Rio de Janeiro State University Institute of Psychology, Brazil, e-mail: cpsa@uerj.br 


\section{INTRODUCTION}

Seventeen years after its implementation, the Brazilian National Health Care System - The Single Health System (SHS) [Sistema Único de Saúde - SUS] is presented as a policy that must make universal access to basic health care possible and cutting-edge technology available. However, there are difficulties associated to insufficient material and financial resources, and the disparity of salaries and hierarchical positions, among others. This reality characterizes an internal tension of the system, experienced by health care professionals, engendering a particular way of viewing and facing such difficulties.

The structuring of the SHS involved a large social participation, such as the organization of the civil society in its many sectors (users, service providers, public institutional agents, and others), expressed in concrete events, such as the National Health Conferences, during the heated academic debate around the topic, held since the beginning of the Sanitary Reform Movement ${ }^{(1-3)}$.

The fundamentals of the Brazilian National Health care System transformation are among the political directives consolidated by the Federal Constitution in the national setting. The 1988 Constitution defined the creation of the SHS, which has, as its basic principles, the universal and egalitarian access to actions and services for health care promotion, protection, and recovery. The constitutional text also expresses a clear intention of transferring the power from the center to the periphery, having decentralization as its main axis, reinforcing municipal autonomy and the participation of the community. The municipality is specifically directed to provide health care services to the population; technical and financial cooperation are responsibilities of the Union and the States.

The SHS was fully implemented in 1990 with the approval of laws \#8080 and \#8142, with several important articles receiving presidential vetoes, particularly those regarding the mechanisms of financial resources transference. As such, Article \#35, part of the Organic Law \#8080, is set as the starting point for the construction of a financing system that can favor, instead of hampering, the implementation of the main postulates of the SHS. The health care system should therefore be made effective from a group of actions and health care services provided by federal, state and municipal public organs and institutions, direct and indirect administration, government-funded foundations and, complementarily, by private investors ${ }^{(1)}$.

The ultimate goals of the SHS are characterized as giving assistance to the population based on the model of health care promotion, implying in actions that aim to eliminate or control the causes of diseases and aggravations, i.e., determining or conditioning the emergence of diseases; protecting the health of the population, with specific actions to prevent risks and exposure to diseases and aggravations, i.e., maintaining their health status; and developing health recovery actions in order to avoid death and sequelae in people who have already been struck by morbid processes.

Therefore, the SHS is defined as a national system because it follows the same doctrinal and organizational principles all over the national territory, under the responsibility of the three autonomous governmental spheres: federal, state and municipal. As such, it is not characterized as a service or institution, but a system that becomes effective as a group of units, services and actions that interact towards a common goal.

The construction of the SHS was oriented by a number of ethical/doctrinal principles, which are the universality of services, equality in providing services, and integral care. The universality of services refers to health as a subjective right, implying that everybody is entitled to health care, i.e., health is regarded as a right of citizenship and the duty of the federal, state and municipal governments. Equality in providing services demands the public health care policies to be redistributive, aiming to correct social and regional inequities. Unequal situations require unequal measures, i.e., each of them according to their needs, aiming to provide a higher uniformity. Integral care implies in having all the actions of health care promotion, protection and recovery as parts of an indivisible whole, and in the right of the population to receive integral health care in their needs. It is understood as an articulate and continuous combination of preventive and curative actions and services, both collective and individual, required for each case at all levels of complexity of the system ${ }^{(1,3)}$. With their varying degrees of complexity, the service providers also make up an indivisible whole, configuring a system capable of providing integral assistance. 
Concomitantly, the organization of the SHS is directed by the organizational/operational principles of service decentralization, regionalization and hierarchization of the network and social participation. These comprise strategic objectives that aim to solidify the health care model ${ }^{(4-5)}$. Decentralization represents the redistribution of responsibility for health care actions and services among the many government levels, down to the municipal level. Redistribution of resources and responsibilities among federated entities, based on the understanding that the central level, the Union, must only execute what the local level, municipalities and states, cannot. Administering the SHS becomes the responsibility of the Union, the states and the municipalities, seen as managers of the $\operatorname{SHS}^{(1,3)}$.

Regionalization and hierarchization imply that the SHS network must be organized so that all regions may be capable of having health care services in different levels, articulating from their hierarchization, allowing for a better knowledge of the health problems in a given area. This would favor actions of epidemiologic and sanitary surveillance, vector control, and health education, as well as actions of hospital care at all levels of complexity.

Social participation, in turn, implies in the constitutional guarantee that the population, through its representative entities, should participate in the process of formulation of health care policies and the control of their execution, in all levels, from federal to local, representing the institutionalization of participative democracy and the consequent social control in the health care $\operatorname{area}^{(1,3)}$

In Brazil, after the 1988 Constitution, the SHS institutionalized the action of interest groups by means of the Health Councils, making the participation of organized social groups such as unions, neighborhood associations and churches possible, along with direct representatives of the government, such as health secretaries and ranking technicians. This participation develops from specific legislature, which defines its boundaries, decision scope and participants ${ }^{(1-2,5-7)}$.

Another aspect that characterizes the organization of the system is its political-administrative decentralization, since it instituted the process of municipalization, defining that the municipality itself should develop health care actions to benefit the citizens directly.

Despite difficulties, several authors agree that there have been advances in the decentralization model adopted by the health care policies towards the municipalization of the administration and the definition of the state functions as coordinators of the municipal reference system. As for the federal level, their inducting and regulatory power was augmented, when new transference mechanisms linked to social programs and actions were introduced ${ }^{(8-9)}$.

Even though there were advances in the municipalization process, a distribution of federal, inter-regional and inter-state resources has been observed. This has privileged better-developed states, especially in procedures of high and medium complexity, while those of basic care being more uniform $^{(9)}$. In addition, the decentralization process, based on the constitutional principles of universalization, equality, and social participation, stated in the 1990 Organic Health care Law, shows both advances and drawbacks due to ambiguities, conflicts and contradictions regarding changes in the role of the Brazilian State set in the $1990 \mathrm{~s}^{(10)}$.

From these considerations, the general goal of the integral project, of which this study is part of, is to characterize and compare the processes of constitution and the contents of the social representations and memories of the health care professionals about the implementation of the Brazilian National Health care System, with health care institutions and centers of the city of Rio de Janeiro. In this text, the contents and structure of social representation of the SHS for the group of professionals studied will be analyzed, aiming to identify and characterize the health care policies made effective and the different health care practices developed.

\section{METHODOLOGICAL APPROACH}

The pertinence of the association of the social memory's theoretical framework, defined as a group of past representations ${ }^{(11-13)}$ and a stable element of representation located in the central nucleus of this study, is justified by the political, economical, and strategic importance of the health care system for the public health care policies in Brazil. Moreover, it is just as well as established by the time that has passed since the implementation of the SHS and the municipalization of health care in Rio de Janeiro, which enables the analysis of this process from the memories built by the health care institutions and the professionals in their role of institutional interlocutors. 
The social representations theory, defined in the scope of social psychology, was adopted in association with this framework, using a complementary proposal to this theory - the structural approach or the central nucleus theory ${ }^{(14-17)}$.

It should be highlighted that a representation is made up of a group of beliefs, information, opinions, and attitudes towards a given social object, becoming a sociocognitive system of a specific type ${ }^{(13-16)}$. The structural approach considers that the organization of a social representation presents a specific characteristic, the organization around a central nucleus, becoming one or more elements that give meaning to the representation ${ }^{(16,17)}$.

The methodological design of the integral project involved five health care institutions in the city of Rio de Janeiro, established 15 years ago or longer, to guarantee that they had built a history within the Brazilian health care system. The choice of the institutions was guided by the following criteria: one public federal high-capacity hospital; a state general high-capacity hospital; a city hospital; a private, highcapacity hospital working as a partner of the SHS for at least 15 years; and a high-capacity health center, belonging to the municipal public health care network. All of the five institutions were located in the municipality of Rio de Janeiro, easily accessible to the population and with a history as a health care provider starting before the implantation of the SHS.

Data collection was done in the first semester of 2003 , with 100 professionals who developed actions in the selected institutions, being 20 in each unit, who had been working in their respective institutions for 15 years or longer. The choice of the professionals was directed by the following criteria: five subjects holding non-directive administrative positions; five subjects holding directive administrative positions; 10 subjects involved in operational activities, with five of these having university degrees and the other five with elementary or high-school level education.

Data collection was executed with the free evocation or word association technique, with aims to apprehend the perception of reality from a preexisting semantic composition, which is not only concrete, but also imagetic and organized around a few simple symbolic elements. The practical application of the technique consists in asking the subjects to quickly and freely associate words or expressions after hearing or visualizing inducting words (stimuli).

Free evocation is presented as an important technique for the collection of constitutive elements of the content of a representation, and it allows for the identification of the structure where such representation is organized ${ }^{(16-17)}$. The inducting term for the collection of free evocations in this study was the expression "Brazilian National Health care System" (SHS), to which the subjects should associate five words or expressions that came to mind immediately.

The analysis of the data combines the association of two criteria: the frequency of mentioning the words and the order in which they were evoked. Cross-referencing these criteria produces a four-area chart where the evocations are arranged ${ }^{(17)}$.

The product of the evocations was organized previously, constituting a corpus for analysis, with the natural order of the subject's evocations being preserved.

Regarding the ethical aspects of the research, the principles of resolution 196/96 were respected, with each institution authorizing the development of the study and with each subject signing a consent form.

\section{RESULTS}

The analysis of the evocation corpus of all the subjects revealed that 444 words were mentioned; the average order of evocation was 2.7 (in a scale of 1 to 5 ). Considering that the evocations whose frequency was equal or inferior to eight were disregarded, the average evocation frequency value was 13.

The combined analysis resulted in a four-area chart, shown below, with the central, peripheral and contrasting elements that define the representation being studied.

Table 1 - demonstrative table of the four-area chart of the group of subjects under study, professionals of the five health care institutions. Rio de Janeiro, 2003.

\begin{tabular}{|c|c|c|c|c|c|c|c|c|}
\hline \multirow{2}{*}{$\begin{array}{c}\text { A.O.E. } \\
\text { Average } \\
\text { frequency }\end{array}$} & \multirow{2}{*}{$\begin{array}{c}>\mathbf{2 . 7} \\
\text { Term evoked }\end{array}$} & \multicolumn{7}{|c|}{$<2.7$} \\
\hline & & \multicolumn{3}{|c|}{ Posit. Freq.A.O.E. } & \multirow[t]{2}{*}{ Term evoked } & \multicolumn{3}{|c|}{ Posit. Freq.A.O.E } \\
\hline \multirow[t]{5}{*}{$>13$} & Service & +- & 33 & 2.68 & & + & 18 & 3.11 \\
\hline & Bad & & 33 & 2.57 & & & & \\
\hline & Health conditions & +- & 16 & 2.48 & & & & \\
\hline & SHS & +- & 15 & 1.86 & & & & \\
\hline & Does not work & - & 13 & 2.65 & & & & \\
\hline \multirow[t]{7}{*}{$<13$} & Aid & + & 12 & 2.50 & Necessary & + & 11 & 3.09 \\
\hline & Equality & & 12 & 1.75 & Right & + & 10 & 3.50 \\
\hline & Disorganized & - & 10 & 2.40 & Professional action & +- & 9 & 3.00 \\
\hline & Unification & +- & 9 & 1.55 & Service to the poor & +- & 9 & 2.77 \\
\hline & Lie & - & 8 & 2.50 & Disease & +- & 9 & 2.88 \\
\hline & Ease & + & 8 & 2.25 & Will turn out well & + & 8 & 3.37 \\
\hline & & & & & Lack of attention & - & 8 & 3.12 \\
\hline
\end{tabular}


The lexicons situated on the upper left quadrant are those of higher frequencies and the most readily evoked, thus constituting the central nucleus of the representation ${ }^{(13,16-17)}$. It should be highlighted that the nuclear elements function in defense of the representation, being less sensitive to changes due to external contexts or the subjects' daily practices.

The representational contents present in the central nucleus are spread out in three main dimensions, with one of them being related to the system goals (service and health conditions), another being an evaluation (bad and does not work), and finally, the imagetic (the abbreviation of the system itself, SHS). The representation of the SHS for the subjects is presented as characteristically negative, a fact detected by the presence of negative elements in the evaluative dimension and strengthened by the absence of positive elements in the context of the remaining dimensions.

It may be considered that elements of the group's social memory might have been present in the constitution of its representation. As such, the service lexicon seems to strengthen what several authors $^{(4,6)}$ postulate as a fundamental characteristic of the SHS - universal and unrestricted service. According to the mental cartography of the professionals, the Brazilian sanitary history has a fundamental division, found in the process of service/ non-service offered by the Health care System ${ }^{(6)}$.

At the same time, the evaluative dimension explores individual experiences, memories shared by the collectivity where one is inserted and the representations that are formed and spread by the media, wherein the SHS is associated to situations of utter chaos and outdated institutions. Non-working and its attributed qualification of bad are closely related to the negation of service in its daily performance within the system, since this element is presented as the most characteristic of the SHS, at least in its qualitative analysis.

It is also important to highlight that the word bad brings along a group of expressions such as chaos, precarious, mess, outdated, no good service, lack of service, lack of conditions, found wanting and deficient. For example, while the expression does not work groups ideas such as did not advance, cannot be counted on, it is flawed in practical terms, not implanted satisfactorily and not working, among others. Therefore, the term bad has the highest frequency and the third lowest rank, and seems to express how the subjects represent the SHS in its general aspects - an inference that seems to be reinforced by the expression does not work.

On the other hand, the representational structure becomes more complex due to the subjects mentioning the legal and theoretical goals recommended for the SHS, as noticed by words such as service and health conditions. The counterpoint to the relation established between bad and service is expressed through health conditions, which seems to indicate the importance of the SHS for the population's health care service.

As seen before, the abbreviation SHS indicates an imagetic dimension of the subjects regarding the public health care system, since its own denomination is evoked. This dimension confers an almost-tangible corporeality to the system from the mental reconstruction of the SHS itself, performed by the professionals, since the aforementioned abbreviation seems to possess, among other elements, the status of a word that replaces expressions such as health care system, for example.

The words with lower frequencies, but readilyevoked, are situated in the lower left quadrant, named contrast zone, comprehending distinct meanings of those in the central nucleus and capable of characterizing variations of the representation among subgroups $^{(16)}$

In this space of the representational structure, the reaffirmation of the negative attitude present in the central nucleus, referring to the functionality of the system (disorganized and lie); and a positive attitude, referring to the care offered to the users of the service (help and ease), reaffirming the positive stand present in the peripheral elements.

However, the contrast zone is made of two elements that allow for the visualization of the implementation, by the professionals being studied, of some basic principles predicted in the Brazilian health care system in its organic law ${ }^{(4,18)}$. The word unification takes the first place in importance in the analysis of its average order of evocation. Furthermore, it reaffirms one of the main characteristics of the SHS as a unified system of health care actions and services involving all three levels of government - municipal, state and federal - in collectively shared responsibilities, in addition to private services acting complementarily with the action of the state. The term equality is the second in importance in the analysis of average order of 
evocation. It elicits the notion of equal rights in the access and utilization of the health care services, leading to the doctrinal principle of universality. The latter implies in entitling everybody with the right to health care service, i.e., health is considered to be a right of citizenship and a duty of the state; and also to the principle of equity, stemming from the premise that all citizens are equal when it comes to the health care system and will receive service as his/her needs dictate.

The apprehension of the highlighted principles, however, cannot be considered consensual in the social group under study, but simply as a content that has been incorporated by one or more subgroups to the representation of the SHS. This hypothesis and the exploration of the social anchoring where these principles are manifested should be analyzed and explored in further studies, as a way to determine which social characteristics are sources of tension for the representation when incorporating legal text.

Such fact draws attention because the integration of the system and the group representation did not occur fully, despite the development of dayto-day actions performed by the professionals within the system. At that moment, the negative aspects coming from its operationalization seem to bypass the main orientations present in its theoretical and legal foundation, especially considering that 17 years have passed since the laws were passed and implemented.

However, the broadening of the basic network and the continuous efforts for the construction of an integrated service network allowed for an increased health care coverage for the population and a physical proximity with the professionals and the health care units. This is made clear here by the positive elements of social representation. It is important to highlight that the presence of positivism and negativism in the representation structure is not seen as a contradiction, but as an exhibition of the tensions within. Such tensions make evident, among other things, the mutual implications between representations and practices, where the central nucleus provides meaning to everyday actions and these, in turn, can influence the transformation of the representation ${ }^{(16)}$.

In the upper right quadrant it is possible to see words that also had a high frequency, but whose average position in the order of evocation was not enough to make them part of the central nucleus, being named the first periphery. In this space of the representational structure, the reaffirmation of a positive stand being taken regarding the SHS can be observed, especially when it comes to its functionality (good).

The positivism present in the first periphery is shown expanded in the second periphery, featured by the words placed in the lower right quadrant, words with lower frequencies and evoked late, and are related to the interface of representation with everyday realities and social practices. The positive aspect of this part of the representational structure seems to indicate the solutions provided by the SHS to the main health problems of the population. In this sense, the possibility of access to health care actions and services can be highlighted as a right of citizenship and symbolically apprehended as the recovery of important dignity facets of specific social groups, regardless of the social class or insertion in the job market $^{(5)}$

In this structural space of the representation of the SHS, the reaffirmation of a positive stand regarding the SHS can also be observed, recognizing it as a right and necessary, but, at the same time, revealing goals such as providing health care to the poor and to disease. This denies the character of uniqueness highlighted in the zone of contrast, as well as the SHS being directed to health conditions, as revealed in the central nucleus.

However, it must be considered that the elements included there are those who are mutant from the representation, oscillating in function of the social pressures undergone by the group. This clearly reveals the aggressions endured by the representation due to the practices developed and the variations in the external context, which may explain the presence of the words mentioned ${ }^{(6-7,16)}$.

In that quadrant, the demands and difficulties of the health care professionals inserted in the SHS can be observed, regarding the interests and demands of the population observed in the everyday performances of the health care professionals.

Thus, the SHS comes out as necessary and a right, conferring an aura of indispensability to the system in the context of health care, in addition to the recognition of one of the basal points of the Brazilian health care policy, which is its understanding as a citizen's right and duty of the state.

At the same time, it unfolds pragmatically in the expressions professional action and service to the poor, incorporating everyday service practices to the 
representation, and the primary target of this service, allowing for the inference that only the poor, who do not have a choice, accept to receive health care in a deficient system that does not work.

\section{CONCLUSIONS}

The results discussed in this study reflect the real SHS, i.e., that system that has been implemented and reconstructed by the health care professionals by means of its main characteristics, such as not fully incorporating philosophical/doctrinal or organizational objectives of the SHS; taking a negative stand regarding the grouping of the health care system and its execution; a positive modulation referred to the benefits incorporated by specific social groups, starting with the universalization of health care services.

The dimension of the attitudes, present in the representation, reveals two distinct positions: one, negative, referring to the difficulties faced to implement the SHS, and another, positive, regarding the rights guaranteed by the new system.

Universal access to actions and services was the most commonly-elicited principle of the SHS by the professionals, being also identified with the most important differential aspect in relation to the previous health care model. At the same time, in the professional representation, the clientele of the services has presented characteristics of pauperization compared to the users of the previous system.

Considering that the construction of a representation implies in the incorporation of several elements, such as relative knowledge of SHS goals, its principles, and its internal dynamics. It also implies in taking a stand regarding this system, either accepting it or not. It is observed, in the structure assumed by the elements, a fledgling representation or a progressive transformation, characterized by

\section{REFERENCES}

1. Brasil. Constituição da República Federativa do Brasil. 05 de outubro de 1988. São Paulo (SP): Atlas; 1991.

2. Campos GWS. Análise crítica das contribuições da saúde coletiva à organização das práticas de saúde no SUS. In: Fleury S, organizadora. Saúde e democracia: a luta do CEBES. São Paulo (SP): Lemos Editorial; 1997. p.113-24

3. Brasil. $8^{\text {a }}$ Conferência nacional de saúde. Brasília (DF): Ministério da Saúde; 1986.

4. Negri B, Viana ALA, organizadores. O Sistema Único de Saúde em dez anos de desafio. São Paulo (SP): Sobravime; 2002. strongly-present negative attitudes, and positive attitudes that start being incorporated to the representation, hence its presence in the peripheral and contrast zones, instead of the central nucleus.

On the other hand, elements relative to the incorporation of new knowledge about the precepts of the SHS were observed, both on central and peripheral levels of the representation. This confirms the hypothesis of a fledgling or transforming representation. It should also be highlighted that the presence of the notions of non-universality of the SHS and its direction towards diseases - archaic notions that are still manifested in the professional mindset reflect part of the Brazilian social mindset that associates public policies to poverty and services lacking in quality.

It is concluded that the SHS, 17 years after its implementation, has allowed for the formation of social representations among health care professionals, who identify the SHS as a health care system different from its predecessor. The content of the SHS representation incorporates some of the principles predicted in its establishing documents, which reflects only their partial and fragmented incorporation.

It is also believed that such incorporation has not been happening naturally, but eliciting the taking of sides by the health care professionals about the very pertinence of these new principles of public health care regarding the current Brazilian context. A hypothesis that the social representation of the SHS is in a process of fledgling or progressive transformation can be postulated, considering the multiple tensions observed in the contents under analysis. These tensions, in turn, point to the need of continuous analysis in order to better identify the variations of representation among subgroups of professionals, considering their social characteristics.

5. Aguilera CE, Bahia L. A história das políticas de saúde no Brasil. In: Aguilera CE, Bahia L, organizadores. Temas de Políticas de Saúde. Rio de Janeiro (RJ): Universidade Federal do Rio de Janeiro; 1993. p. 3-13.

6. Carvalheiro JR. Os desafios para a saúde. Estudos avançados 1999 janeiro-abril; 13(35):7-20.

7. Barros MED. Política de Saúde: a complexa tarefa de enxergar a mudança onde tudo parece permanência. In: Canesqui AM, organizador. Ciências Sociais e Saúde. São Paulo (SP): Hucitec/Abrasco; 1997. p. 113-33.

8. Levcovitz E, Lima LD, Machado CV. Política de saúde nos anos 90. Ciênc Saúde Coletiva 2001; 6(2):269-81. 
9. Ugá MA, Piola SF, Porto SM. Descentralização e alocação de recursos no âmbito do Sistema Único de Saúde (SUS). Ciênc Saúde Coletiva 2003; 8(2):417-27.

10. Cordeiro H. Descentralização, universalidade e eqüidade nas reformas da saúde. Cienc Saúde Coletiva 2001; 6(2):319-28.

11. Halbwachs $M$. Les cadres sociaux de la mémoire. Paris(PA): Albin Michel; 1994.

12. Le Goff J. Histoire et mémoire. Paris (PA): Gallimard; 1988.

13. Sá CP. Representações sociais e memória coletiva de um acontecimento remoto. In: Lemos, MTTB, Lemos NAM, Leira, $\mathrm{PA}$, organizadores. Memória e identidade. Rio de Janeiro (RJ): Sete Letras; 2000. p. 27-41.

14. Moscovici S. La Psychanalyse, son image et son public. Paris (PA): P.U.F.; 1976.

15. Jodelet $D$. Représentations sociales: un domaine en expansion. In: Jodelet $D$, organizadora. Les représentations sociales. Paris (PA): Presses Universitaires de France; 1989. p. 17-44.

16. Abric JC. A zona muda das representações sociais. In: Oliveira DC, Campos PHF, organizadores. Representações sociais, uma teoria sem fronteiras. Rio de Janeiro (RJ): Ed. Museu da República; 2005. p. 23-34.

17. Vergès P. Appoche du noyau central: proprietès quantitatives et structurales. In: Guimelli $C$, organizador. Textes de Base in Sciences Sociales: Structures et Transformation des Représentations Sociales. Paris (PA): Delachaux et Niestlé; 1994. p. 233-53.

18. Assis MMA, Villa TCS. O controle social e a democratização da informação: um processo em construção. Rev Latino-am Enfermagem 2003 maio-junho; 11(3):37682. 